\title{
Spor salonunda spor yapan kişilerde glda takviyesi kullanım durumunun saptanması
}

Özde Ezel ORUÇ GÜLER ${ }^{\mathrm{a}}$, Nejla ANUL ${ }^{\mathrm{b}}$

\section{ÖZET}

Amaç: Bu çalışma spor salonunda spor yapan kişilerin gıda takviyesi kullanım durumu belirlemek amacıyla yapılmıştır. Yöntem: İstanbul'da özel bir spor merkezinde 75 katılımcı ile 34 sorudan oluşan anket uygulaması ile gerçekleştirilmiştir. Anket verileri SPSS 24.0 paket programı kullanılarak analiz edilmiş olup verilerin değerlendirilmesinde frekans analizi, ortalama, minimum maksimum değer, standart sapma ve parametrik olmayan bulgular için Ki-kare testi kullanılmıştır. Çalışmanın etik kurul onayı alınmıştır. Bulgular: Gıda takviyesi kullanım durumuna bakıldığında; katılımcıların \%65.3'ü kullanmadığını, \%28'i sürekli kullandığını ve \%6.7'si bazen kullandığını bildirmiştir. Gıda takviyesi kullanan kişilerin \%50'si kas geliştirme, \%19.2'si form tutma, \%19.2'si yağ yakımı ve \%11.5'i ise performans arttırma amacıyla gıda takviyesi kullanmakta olup, gida takviyesi kullanan kişilerin \%53.8'i protein tozu, \%23.1'i dall zincirli amino asit, \%7.7'si aminoasit, \%7.7'si kreatin, \%3.8'i konguje linoleik asit ve \%3.8'i L-karnitin kullandığı belirtilmiştir. Gida takviyesi kullanan kişilerin \%46.2'si spor eğitmeni, \%34.6'sı kendi isteği ile \%15.4'ü arkadaşı ve \%3.8'i diyetisyen tarafından gida takviyesi kullanımına yönlendirildiğini, gıda takviyesine ulaşımın \%42.3'ünün internet, \%23.1'inin eczane, \%19.2'sinin spor eğitmeni ve \%15.4'ünün mağaza yoluyla olduğu belirtilmiştir. Sonuç: Eğitim durumu ve gıda takviyesi kullanımı arasındaki ilişki anlamlı olduğu ve gıda takviyesi kullanımının eğitim seviyesi arttıkça arttığı sonucuna ulaşılmıştır. Egzersiz çeşidi ve protein tozu kullanımı arasındaki ilişki ise anlamsız bulunmuştur.

Anahtar Sözcükler: Egzersiz, sporcu beslenmesi, spor salonu, gıda takviyesi

\section{Determination of food supplement usage status of people in the gym}

\begin{abstract}
Objective: This study was carried out in order to determine the use of food supplements in the gym. Methods: The study was carried out with a questionnaire application consisting of 34 questions with 75 participants in a private sports center in Istanbul. The survey data were analyzed using the SPSS 24.0 package program, and frequency analysis, mean value, minimum maximum value, standard deviation and nonparametric findings were evaluated using the Chi-Square Test. Ethics committee approval of the study was given by Demiroğlu Bilim University Clinical Research Ethics Committee. Results: According to the results of the study, $65.3 \%$ of participants did not use food supplement, $28 \%$ used continuous food supplement and $6.7 \%$ sometimes used food supplement. $50 \%$ of people using food fortification stated that they use muscle strengthening, $19.2 \%$ form retention, $19.2 \%$ fat burning and $11.5 \%$ use food reinforcing to improve performance. $53.8 \%$ of the subjects were using protein dust, $23.1 \%$ were branched chain amino acid, $7.7 \%$ amino acid, $7.7 \%$ creatine, $3.8 \%$ conjugated linoleic acid and 3.8\% L-carnitine. $46.2 \%$ of the people using food supplement were sport trainers, $34.6 \%$ were self-employed, $15.4 \%$ were friends and $3.8 \%$ were directed by a dietitian to use food supplement. It is stated that $42.3 \%$ of the people who use food supplement use the Internet, $23.1 \%$ to pharmacy, $19.2 \%$ to train sports and $15.4 \%$ to provide food supplements through stores. Conclusions: The relationship between education status and food supplement use was found to be significant and the use of food supplementation was achieved as the level of education increased. The relationship between exercises type and protein dust use was found to be meaningless.
\end{abstract}

Keywords: Exercises, sports nutrition, gym, food supplement

\footnotetext{
Geliş Tarihi: 13.05.2020

Kabul Tarihi: 10.12 .2020

aÖzel Tinaztepe Torbalı Hastanesi / Ekol Göz Menemen Spor Kulübü, İstanbul, Türkiye, e-posta: orucezel@gmail.com ORCID: 0000-0001-9827-5376 bístanbul Demiroğlu Bilim Üniversitesi Sağlik Bilimleri Fakültesi Beslenme ve Diyetetik Bölümü, İstanbul, Türkiye, e-posta: tanul2023@gmail.com ORCID: 0000-0001-9747-2968

Sorumlu Yazar/Correspondence: Özde Ezel Oruç Güler ｅ-posta: orucezel@gmail.com

Atıf: Oruç Güler ÖE, Anul N. Spor salonunda spor yapan kişilerde gıda takviyesi kullanım durumunun saptanması. Sağllk ve Yaşam Bilimleri Dergisi 2020;2(2):43-48

Citation: Oruc Guler OE, Anul N. Determinition of food supplement usage status of people in the gym. Journal of Health and Life Science 2020;2(2):43-48.
} 


\section{GíRiş}

Dünya genelinde teknolojinin hızlı gelişimi, şehirleşmenin artması, çalışma koşullarının değişmesi sonucunda insanlar hareketsiz ve sağlıksız bir yaşam çevresi ile karşılaşmaktadır. Ağır çalışma koşulları, yapılaşmanın her geçen gün artması, doğal spor alanların azalması, insanların doğada özgürce spor yapmasını zorlaştırmaktadır. İnsanların spor yapabileceği uygun spor ortamlarının bulunmaması, yerleşim yerlerinde spor salonlarının çoğalmasına ve Spor salonunda egzersiz ve spor yapan birey sayılarının artmasına yol açmıştır. ${ }^{1}$

Spor; tek başına ve toplu olarak yapılan, kendine özgü kuralları olan, genelde yarışmaya dayanan bedensel ve zihinsel yeteneklerin gelişimini sağlayan eğitici ve eğlendirici uğraşlardır. İnsanları spor yapmaya iten nedenler ise;

- Sağlık, rehabilitasyon ve fiziksel uygunluk sağlama,

- Belirli sosyal ihtiyaçları karşılama,

- Spor yoluyla bilgece deneyimler kazanma,

- Duygusal gerilimden kurtulma,

- Estetik ihtiyaçları doyurma,

- Boş zamanı ortaklaşa, aktif ve verimli bir şekilde değerlendirme,

- Güç, hız, dayanıklılık, çeviklik ve koordinasyon yeteneğini geliştirme istekleridir. $^{1}$

Spor yapan kişilerin spor performanslarını etkileyen nedenler: sosyal, psikolojik, bilişsel, kondisyonel, bedensel, teknik ve taktik faktörlerdir. Ancak kişilerin spordan maksimum yarar sağlaması için bu nedenlerden en önemli olanları kondisyonel faktörler içerisinde yer alan antrenman türü ve bedensel faktörler içerisinde yer alan genetik yapı ve beslenmedir. $^{2}$

Fiziksel uygunluğa erişmek isteyen kişiler için egzersiz programlarının üç temel bileşeni vardır. Bunlar egzersiz sıklığı, egzersiz şiddeti ve egzersiz süresidir. $\mathrm{Bu}$ bileşenler egzersiz programını oluşturmakta ve böylece egzersiz programı kişiye özel olarak planlanmalıdır. $^{2}$

Antrenman, spor yapan kişinin belirli bir plan, program içerisinde fizik ve moral gücünün, teknik-taktik becerilerin organik ve psikolojik yüklenmelerle düzeltilmesi, en üst düzeye getirilmesi amaçlarına yönelik sürekli ve belirli aralıklarla yapılan eğitim sürecidir. ${ }^{3}$ Egzersiz türleri kuvvet, dayanıklılık, esneklik ve denge olmak üzere dört gruba ayrılmaktadır ve kişiler hedeflerine uygun olarak egzersiz türünü seçmelidir. ${ }^{4}$

Beslenmede ise amaç, yaş, cinsiyet, fiziksel çalışmaya göre gereksinen bütün besin öğelerini ve harcanan enerjiyi yeterli oranlarda sağlamaktır, bu iki önemli faktör birbiriyle uyumlu ve başarı ile gerçekleştiğinde kişiler hedeflerine daha kolay ulaşmaktadır. ${ }^{5}$

Sağlıklı beslenme konusunda bilinçlenen insanlar, vücutlarında özel fizyolojik etkiler oluşturan, hastalıklarından koruyan ve hastalıkların oluşma riskini azaltan, takviye gıdalara yönelmektedir. ${ }^{6}$ Gıda takviyeleri (besin destek ürünleri), 1994 yılında Amerikan Diyet Suplemanı Sağlık ve Eğitimi Dairesi (Dietary Supplement Health and Education Act) tarafından beslenmeyi desteklemek amacıyla alınan bir ya da birden fazla vitamin, mineral, bitki (tütün hariç), aminoasit konsantresi, metaboliti, bileşeni veya kombinasyonu şeklindeki ürünler olarak tanımlanmıştır. ${ }^{7}$

G1da takviyeleri (besin destekleri), beslenme ile besin alımının yetersiz olması, besin ögeleri alımının önerilen miktarların altında olması, özel durumlara bağlı olarak besin gereksinimlerinin artması ve hücre işlevlerinin düzeltilmesi için farmakolojik etki beklentisinin olması gibi durumlarda uygulanır. ${ }^{8}$ Gida takviye ürünleri etki ve etkinliklerine göre sinıflandırılır. Gida takviyeleri etkilerine göre kas oluşumunu destekleyen, vücut ağırlığını azaltan ve performans geliştiren, enerji veren; etkinliğine göre; etkinliği olan, etkinliği olası, etkinliğini söylemek için henüz erken ve etkin değil şeklinde gruplandırılmıştır. ${ }^{2}$

Amerika Birleşik Devletleri (ABD)'nde yüksek oranda güçlendirilmiş gıda ve ek ürünlerinin kullanımına yönelik yapılan bir araştırmada da enerji barları, enerji içecekleri, sporcu içecekleri, protein barları ürünlerin tüketiminin popüler olduğu belirtilmiştir. ABD'de nüfus sayımı verilerini yansıtmak için dengelenmiş web tabanlı bir anket uygulanarak 2011 yılında 2355 ABD'li yetişkinin takviye gıda kullanımlarını ve 2005 yılındaki kullanım nedenlerini açıklamak için yapılan araştırmada, yetişkinlerin \%33'ünün takviye gida kullandığı bildirilmiştir. Kullanıcıların \%46'sı spor içeceği, \%37'si güçlendirilmiş yiyecek veya içecek, \%32'si protein barı, \%27'si enerji içeceği, \%27'si enerji barı, \%12'si enerji jelleri kullanmaktadır. İki bin beş yılında yüksek güçlendirilmiş ürün kullananların oranı \%36 $(n=2039), 2009$ yilında \%35 $(n=2010)$ ve 2011 yılında \%30 $(n=2355)$ oranında tespit edilmiştir. Yeterli ve dengeli beslenmenin, spor performansının geliştirilmesi için temel etkenlerinden olduğunu destekleyen birçok yayın olmasına rağmen spor yapan kişilerin gıda takviyesi kullanımı hızla artmaktadır. ${ }^{9}$

Gıda takviyelerinin bilinçsiz kullanımı sonucunda, örneğin yağda eriyen vitaminlerin (A, D, E, K) fazla miktarda tüketilmesi bu vitaminlerin vücutta depolanmasına neden olur. Vücuttan atılamayan vitaminler vücutta toksik hale gelerek kişilerin ölümüne yol açmaktadır. ${ }^{10}$ Sporcular tarafindan kullanılan gida takviyeleri uzman bir kişi tarafindan 
düzenlenmelidir. Gıda takviyeleri içerisinde bulunan bileşiklerin uyarıcı veya doping listesinde yer alması müsabakalarda diğer sporcularla eşit koşullarda yarışma şartını ortadan kaldırarak sporcu sağlığını da tehlikeye atmaktadır. ${ }^{6}$ Bu çalışma spor salonunda spor yapan kişilerin gida takviyesi kullanım durumu belirlemek amacıyla yapılmıştır.

\section{YÖNTEM}

Bu çalışma Aralık 2016 - Şubat 2017 tarihleri arasında İstanbul'da özel bir spor merkezinde çalışmaya katılmayı kabul eden 75 kişi ile yüz yüze görüşme yöntemiyle, anket uygulaması yapılarak tamamlanmıştır. Katılımcıların boy-kilo, vücut yağ kütlesi ve yağsız vücut kütlesi verileri vücut analiz cihazı ile sağlanmıştır.

Çalışmada elde edilen verilerin istatiksel analizi için IBM SPSS Statistics 24.0 programı kullanılmıştır. Çalışma verilerinin değerlendirilmesinde frekans analizi, ortalama, minimum-maksimum değer, standart sapma, ayrıca eğitim durumu ve gıda takviyesi kullanımı ile spor türü ve protein tozu kullanımı arasındaki ilişki nonparametrik analiz yöntemi olan Kikare testi kullanılarak tespit edilmiştir. Anlamlılık sınırı $\mathrm{p}<0.05$ olarak kabul edilmiştir.

\section{BULGULAR}

Vücut analizi ortalama değerleri; boy uzunluğu $173.32 \pm 9.36 \mathrm{~cm}$; vücut ağırlığı $71.33 \pm 13.50 \mathrm{~kg}$, vücut kütle indeksi $23.50 \pm 3.22 \mathrm{~kg} / \mathrm{m}^{2}$; vücut yağ oranı $\% 19.40 \pm 6.62$; yağsız vücut ağırlığ $\breve{1}_{1}$ oran1 $\% 71.24 \pm 9.29$; vücut su oranı $\% 54.61 \pm 3.53$ olarak saptanmıştır (Tablo 1).

Tablo 1. Vücut analiz değerleri

\begin{tabular}{lrrrr}
\hline Özellikler & Ort. & SS & Min & Max \\
\hline Yaş & 27.33 & 7.43 & 16 & 53 \\
Boy uzunluğu $(\mathrm{cm})$ & 173.32 & 9.36 & 154 & 190 \\
Vücut ağırlığı $(\mathrm{kg})$ & 71.33 & 13.50 & 49 & 110 \\
BKI $\left(\mathrm{kg} / \mathrm{m}^{2}\right)$ & 23.50 & 3.22 & 18 & 35 \\
Vücut yağ oranı (\%) & 19.40 & 6.62 & 6 & 39 \\
Yağsız vücut ağırlığ & 71.24 & 9.29 & 52 & 90 \\
oranı (\%) & & & & \\
Vücut su oranı (\%) & 54.61 & 3.53 & 44 & 60 \\
\hline
\end{tabular}

Katılımcıların \%41.3 (n=31)'ü kadın \%58.7 (n=44)'si erkektir, yaş ortalaması 27.33 $\pm 7.43, \% 52 \quad(n=39)$ 'si üniversite, \%29.3 (n=22)'ü lise ve dengi, \%14.7 $(n=11)$ 'si lisansüstü, \%2.7 (n=2)'si açık öğretim, \%1.3 $(\mathrm{n}=1)^{\prime}$ '̈̈ ise ilköğretim mezunudur. Katılımcıların \%42.7'si haftada 3-4 gün, \%29.3'ü haftada 5-6 gün, $\% 20$ 'si haftada 1-2 gün, \%8'i ise her gün egzersiz yapmaktadır. Katılımcıların \%54,7'sinin kardiyo ve \%45.3'ünün güç çalışması yaptığı saptanmıştır (Tablo 2).
Katılımcıların gıda takviyesi ile ilgili düşüncelerinde \%24'ü sağlığa sakıncalı olduğunu, \%24'ü zor durumda kalmadıkça kullanımının çok gereksiz olduğunu, \%17.3'ü sağlıklı ve faydalı olduğunu, \%16'sı fast food yerine tercih edilebileceğini, \%14.7'si spor yapanlar için olmazsa olmaz olduğunu ve \%4’ü doğal ürünlerden daha etkili olduğunu belirtmiştir. Katılımcıların \%36'sı kas kütlesini arttırmak, \%34.7'si kilo vermek, \%9.3'ü düzensiz beslendiği için kolay çözüm olduğunu, \%9.3'ü vakit yetersizliği, \%5.3'ü istediği yiyeceği hazırda bulamaması, \%4'ü enerji sağladığını ve \%1.3'ü besin desteklerini daha lezzetli bulduğu için gıda takviyesi kullanımına yönlendiğini belirtmişlerdir. Katılımcıların \%28'i sürekli gıda takviyesini kullandığı ve \%6.7'si ise bazen gida takviyesi kullandığını, \%50'si kas geliştirme, \%19.2'si form tutma, \%19.2'si yağ yakımı ve \%11.5'i ise performans arttırma amaciyla kullandığını belirtmişlerdir. Gıda takviyesi kullanan kişilerin $\% 18.7$ 'si protein tozu, \%8'i dall zincirli amino asit, \%2.7'si amino asit, \%2.7'si kreatin, \%1.3'ü konjuge linoleik asit ve \%1.3'ü L-karnitin kullandığını belirtmişlerdir. Protein tozu kullanan kişilerin \%12'si 1-2 ölçek, \%8'i 1 ölçek ve \%2.7'si 3-5 ölçek kadar protein tozu kullandığını belirtmişlerdir. Katılımcıların \%16's1 spor eğitmeni, \%12'si kendi isteği ile, \%5.3'ü arkadaşı ve \% 1.3'ü diyetisyen tarafindan gıda takviyesi kullanımına yönlendirildiği belirtilmiştir (Tablo 3).

Tablo 2. Bireysel ve yapılan egzersiz ile ilgili özellikler

\begin{tabular}{lrr}
\hline & $\mathrm{n}$ & $\%$ \\
\hline Cinsiyet & 31 & 41.3 \\
Kadın & 44 & 58.7 \\
Erkek & & \\
Öğrenim durumu & 11 & 14.7 \\
Lisansüstü & 39 & 52 \\
Üniversite & 2 & 2.7 \\
Açıköğretim & 22 & 29.3 \\
Lise ve dengi & 1 & 1.3 \\
İlköğretim & & \\
Egzersiz çeşidi & 41 & 54.7 \\
Kardiyo & 34 & 45.3 \\
Güç çalışması & & \\
Egzersiz yapma sıklığı & 6 & 8 \\
Her gün & 22 & 29.3 \\
Haftada 5-6 gün & 32 & 42.7 \\
Haftada 3-4 gün & 15 & 20 \\
Haftada 1-2 gün & & \\
\hline
\end{tabular}

Çalışmada eğitim durumu ve gıda takviyesi kullanımı arasındaki ilişki incelendiğinde lise ve dengi eğitim durumuna sahip kişilerin \%33.3'ü, üniversite mezunlarının \%61.9'u gıda takviyesini kullandığını; belirtmiştir. Eğitim durumu ve gıda takviyesi kullanımı arasındaki ilişki ise yapılan Ki-kare testi sonucunda istatistiksel olarak anlamlı bulunmuştur $(\mathrm{p}=.001)$ (Tablo 4). 
Tablo 3. Gida takviyesi ile ilgili özellikler

\begin{tabular}{|c|c|c|}
\hline & $\mathrm{n}$ & $\%$ \\
\hline \multicolumn{3}{|c|}{$\begin{array}{l}\text { Piyasada bulunan gida takviyeleri hakkında } \\
\text { düșünceler }\end{array}$} \\
\hline Sağlıklı ve faydalılar & 13 & 17.3 \\
\hline Spor yapanlar için olmazsa olmaz & 11 & 14.7 \\
\hline Fast food yerine tercih edilebilir & 12 & 16.0 \\
\hline Doğal ürünlerden daha etkili & 3 & 4 \\
\hline Zor durumda kalmadıkça çok gereksiz & 18 & 24 \\
\hline $\begin{array}{l}\text { Sağlığa sakıncalı olduğunu } \\
\text { düşünüyorum }\end{array}$ & 18 & 24 \\
\hline \multicolumn{3}{|c|}{ GIda takviyesi kullananların motivasyonu ne olabilir } \\
\hline Enerji sağlamak & 3 & 4 \\
\hline $\begin{array}{l}\text { Besin desteklerini daha lezzetli } \\
\text { buluyorum }\end{array}$ & 1 & 1.3 \\
\hline Vakit yetersizliği & 7 & 9.3 \\
\hline Kilo vermek & 26 & 34.7 \\
\hline $\begin{array}{l}\text { Düzensiz beslendiğim için kolay çözüm } \\
\text { oluyor }\end{array}$ & 7 & 9.3 \\
\hline $\begin{array}{l}\text { İstediğim yiyeceği hazırda } \\
\text { bulamıyorsam }\end{array}$ & 4 & 5.3 \\
\hline Kas kütlesini arttırmak & 27 & 36 \\
\hline Gida takviyesi kullanımı & & \\
\hline Evet & 21 & 28 \\
\hline Hayır & 49 & 65.3 \\
\hline Bazen & 5 & 6.7 \\
\hline \multicolumn{3}{|l|}{ Gida takviyesi kullanım amacı $(\mathrm{n}=\mathbf{2 6})$} \\
\hline Form tutma & 5 & 19.2 \\
\hline Yağ yakımı & 5 & 19.2 \\
\hline Kas geliştirme & 13 & 50 \\
\hline Performans arttırma & 3 & 11.5 \\
\hline \multicolumn{3}{|l|}{ Kullanılan gida takviyesi $(\mathrm{n}=26) *$} \\
\hline Amino asit & 2 & 2.7 \\
\hline Protein tozu & 14 & 18.7 \\
\hline Dallı Zincirli Amino Asit (DZAA) & 6 & 8 \\
\hline L-karnitin & 1 & 1.3 \\
\hline Kreatin & 2 & 2.7 \\
\hline Konjuge Linoleik Asit (KLA) & 1 & 1.3 \\
\hline \multicolumn{3}{|l|}{ Protein tozu kullanım miktarı $(n=17)$} \\
\hline 1 ölçek & 6 & 8 \\
\hline 1-2 ölçek & 9 & 12 \\
\hline 3-5 ölçek & 2 & 2.7 \\
\hline \multicolumn{3}{|c|}{ Gıda takviyesi kullanımına yönlendiren kişi $(n=26)$} \\
\hline Spor eğitmeni & 12 & 16 \\
\hline Diyetisyen & 1 & 1.3 \\
\hline Kişinin kendi isteği & 9 & 12 \\
\hline Arkadaş tavsiyesi & 4 & 5.3 \\
\hline
\end{tabular}

Tablo 4. Gıda takviyesi kullanımı ile eğitim durumu arasındaki ilişki

\begin{tabular}{l|c|c|c|c|c}
\hline Gruplar & \multicolumn{2}{|c|}{ Gıda takviyesi kullanımı } & & \multirow{2}{*}{$\mathbf{x}^{\mathbf{2}}$} \\
\hline & Evet & Hayır & Bazen & Toplam & \\
\hline İlköğretim & 0 & 0 & 1 & 1 & \\
\hline Lise & 7 & 15 & 0 & 22 & \\
\hline Üniversite & 13 & 25 & 1 & 39 & .001 \\
\hline Lisansüstü & 1 & 8 & 2 & 11 & \\
\hline Toplam & 21 & 49 & 5 & 75 & \\
\hline
\end{tabular}

Tablo 5'de görüleceği gibi, protein tozu kullanımının egzersiz çeşidi değişkinine bağımlı olup olmadığı belirlemek amaciyla yapılan ki-kare (chi-square) testi sonucunda değişkenler arasındaki bağımlılık istatiksel olarak anlamlı olarak bulunmamıştır. (x2 $=0.252$; $\mathrm{p}>0.05)$.
Tablo 5. Protein tozu kullanımının egzersiz çeşidi ile iliş̧isi

\begin{tabular}{lccccccc}
\hline Gruplar & \multicolumn{2}{c}{$\begin{array}{c}\text { Protein tozu } \\
\text { kullanımı }\end{array}$} & & & & & \\
& Evet & Hayır & Toplam & & & \\
& & & & $\mathbf{x}^{\mathbf{2}}$ & $\mathbf{~ s d}$ & $\mathbf{p}$ \\
\hline Kardiyo & 7 & 37 & 44 & & & \\
$\begin{array}{l}\text { Güç } \\
\text { çalışması }\end{array}$ & 9 & 22 & 31 & .252 & 1 & .172 \\
Toplam & 16 & 59 & 75 & & & \\
\hline
\end{tabular}

\section{TARTIŞMA}

Beslenme; büyüme, gelişme, yaşamın sürdürülmesi ve sağlığın korunması açısından bireylerin yaşamı boyunca sağlıklı olmasının temelini oluşturur. ${ }^{11}$ Sportif performans, dengeli bir beslenme ile gelişebileceği gibi dengesiz beslenme ile olumsuz olarak etkilenebilir. ${ }^{12}$ Günümüzde ister amatör ister profesyonel düzeyde spor yapan kişiler olsun spor sırasında kaybettiği enerjiyi geri kazanmak ve kas geliştirmek amacıyla gida takviyelerine yönelmektedir. Bu ürünlere yönelik alg1, düşünce ve tutumlar ürünün kullanımı üzerinde büyük öneme sahiptir. ${ }^{9}$ Gıda takviyelerinin kontrolsüz ve bilinçdışı kullanımı çeşitli hastalıkların oluşmasına zemin hazırlamakta hatta kişilerin hayatını kaybetmesine yol açmaktadır. $\mathrm{Bu}$ nedenle gida takviyelerinin, sağlık alanında uzman kişiler tarafindan kişiye özel olarak uygulanması gerekmektedir. ${ }^{6}$

Bora'nın spor salonunda çalışan vücut geliştirme ile ilgilenen spor hocalarının beslenme ve takviye destek ürün tüketim durumlarının saptanması üzerine yaptığı çalışmada katılımcıların öğün atlama nedeni sorgulandığında \%68.8'i, bu çalışmada ise katılımcıların \%41.8'inin zaman yetersizliği nedeniyle öğün atladığı belirtmiştir. ${ }^{13}$ Yapılan çalışmalar değerlendirildiğinde günümüzde yaşam koşullarının zorlaşması nedeniyle kişiler en kısa sürede kişisel ihtiyaçlarını gidermeye çalışmaktadır. $\mathrm{Bu}$ nedenle kişiler öğün atlamakta veya en hızlı şekilde besin alternatifleriyle öğün tüketimini gerçekleştirmektedir.

Argan ve Köse'nin fitness merkezi katılımcıları üzerinde yaptığı bir araştırmada katılımcıların \%60.9'unun erkek olduğu, eğitim durumlarının \%71.1 üniversite olduğu ve \%52.8'i g1da takviyesi kullanmadığı belirtilmiş olup yapılan bu çalışmada ise katılımciların \%58.7'sinin erkek; \%61.9 üniversite mezunu ve \%65.3'ü gıda takviyesini kullanmadığını bildirmiştir. ${ }^{6}$ Araştırmalar arasında paralellik olduğu görülmektedir. Gıda takviyesi kullanan kişilerin eğitim seviyelerinin yüksek ve metropollerde yaşayanların daha fazla kullandığı bildirilmektedir. Çalışmalardan elde edilen sonuçlara göre eğitim seviyeleri arttıkça gıda takviyelerinin kullanımının arttığı söylenebilir. ${ }^{14}$

Sobal ve Marquart tarafindan yapılan bir araştırmada adölesan sporcuların \%62'si gıda takviyelerinin performansı arttırdığına inanmakta olup bu çalışmada 
ise katılımcıların \%24'ü gıda takviyelerinin sağlığa zararlı olduğunu düşündüğünü belirtmișlerdir. ${ }^{15}$ Nieper tarafindan İngiltere'de Milli Atletler üzerine yaptığı çalışmada katılımcıların \%65'i antrenörler, \%30'u spor diyetisyeni tarafindan gida takviyesi kullanımına yönlendirilmektedir yapılan bu çalışmada ise katılımcıların \%46,2'si spor eğitmenleri, \%3,8'i ise diyetisyenler tarafindan gida takviyesi kullanımını önerdiği sonucuna ulaşılmıştır. ${ }^{16}$ Yapılan çalışmalarda gıda takviyesi kullanımına daha az oranda sağlık alanında uzman kişiler tarafından yönlendirildiği görülmektedir. Gıda takviyelerinin bilinçsiz ve kontrolsüz kullanımı sağlığı olumsuz etkilemektedir. $\mathrm{Bu}$ nedenle kişilerin sağlık alanında uzman kişilerden yardım alarak gıda takviyelerini kullanması gerekmektedir.

Korkmaz'ın Uludağ Üniversitesi öğrencilerinin spor yapma ve beslenme alışkanlıklarının incelenmesi üzerine yaptığı çalışmada spor yapan katılımcıların $\% 11,4$ 'ünün haftada 3 günden fazla spor yaptıkları bu çalışmada ise katılımcıların \%80'i haftada 3 günden fazla spor yaptıklarını belirtmişlerdir. ${ }^{17}$ Argan ve Köse'nin fitness merkezi katılımcıları üzerinde yaptığı bir araştırmada katılımcıların \%60,9'unun erkek olduğu, eğitim durumlarının \%71.1 üniversite olduğu ve \%52.8'i gıda takviyesi kullanmadığı belirtilmiş olup yapılan bu çalışmada ise katılımcıların \%58.7'sinin erkek; \%61.9 üniversite mezunu ve \%65.3’ü gida takviyesini kullanmadığını belirterek araştırmalar arasında paralellik olduğu görülmektedir. ${ }^{6}$

Yalnız ve Gündüz'ün Ankara ilinde vücut geliştirme branşında faaliyet gösteren sporcuların ergojenik yardımcılar konusunda bilgi ve uygulama düzeyleri üzerine yaptığı çalışmada katılımcıların ergojenik destek ürünlerini \%3.2 internet yoluyla temin ettiği; ergojenik yardım kullanırken ve kullanım sonrası yan etkilerine maruz kaldınız mı diye sorulduğunda katılımcıların \%72.1'i maruz kaldığını bu çalışmada ise katılımcıların \%42.3'ü internet yoluyla gida takviyelerini temin ettiği ve \%29.3'ü gida takviyesi kullanımı sonucunda zarar görmediği sonucuna ulaşı1mıştır. ${ }^{18}$

\section{SONUÇ}

Sonuç olarak bu çalışmada eğitim durumu ve gıda takviyesi kullanımı arasındaki ilişki incelendiğinde eğitim seviyesi ile gıda takviyesi kullanımı arasında doğrusal bir ilişki vardır. Yapılan egzersiz çeşidi ve protein tozu kullanımı arasındaki ilişki Ki-kare testi kullanılarak tespit edilmiş olur test sonucunda egzersiz çeşidi ve protein tozu kullanımı arasındaki ilişki anlamsız bulunmuştur. Beslenme spor performansını etkileyen en önemli etkenlerden biridir. $\mathrm{Ne}$ yazık ki ülkemizde sporcu beslenmesine gereken önem verilmemektedir. Sporcu beslenmesi konusunda eğitimlerin ve bu alanda uzman diyetisyenlerin arttırılarak tüm spor alanlarında diyetisyen bulundurulması gerek sporcu gerekse antrenörlerin beslenme konusunda eksiklerin giderilerek doğru beslenme alışkanlıklarının kazandırılması sağlandırılmalıdır. Doğal beslenme ile karşılanamayan ve artan besin-enerji gereksiniminin diyetisyen kontrolünde kişiye özel olarak gıda takviyeleri kullanımı ile sağlanabilir. Gıda takviyelerinin bilinçsiz ve kontrolsüz kullanımının birçok hastalığ1 beraberinde getireceği unutulmamalıdır.

\section{KAYNAKLAR}

1. Ulukan H. İletişim becerilerinin takım ve bireysel sporculara olan etkisi. Karamanoğlu Mehmetbey Üniversitesi Sosyal Bilimler Enstitüsü Yüksek Lisans Tezi, 2012.

2. Ersoy G. Fiziksel Uygunluk Spor ve Beslenme ile İlgili Temel Öğretiler. 2. Baskı. Ankara: Ankara Nobel Tip Kitapevleri; 2016.

3. Baktaal DG. 16-22 yaş bayan voleybolcularda pliometrik çalışmaların dikey sıçrama üzerine etkilerinin belirlenmesi. Çukurova Ünivesitesi Sağlık Bilimleri Enstitüsü Yüksek Lisans Tezi, 2008.

4. Demirel H, Kayıhan H, Özmert EN, Doğan A. Türkiye Fiziksel Aktivite Rehberi. Ankara, Sağlık Bakanlığı Yayınları. 2014; 1-41.

5. Baysal A, Aksoy M, Besler T ve ark. Diyet El Kitabı. 8. Baskı. Ankara: Hatiboğlu Yayınları; 2014.

6. Argan M, Köse H. Sporcu besin desteklerine yönelik tutum faktörleri: fitness merkezi katılımcıları üzerine bir araştırma. Spor Bilimleri Dergisi. 2009;20(4):152-164.

7. Dietary Supplement Health and Education Act of 1994. Public Law No. 103-417, 108 Stat 4325, 1994.

8. Acar Tek N, Pekcan G. Besin destekleri kullanılmalı mı. Ankara: Sağlı Bakanlığı Yayınları. 2008; 7-17.

9. Costello RB, Dwyer JT, Bailey RL, Saldanha L, French S. Use of highly fortified products among US adults. Nutr Today. 2015;50(6):294-300.

10. Özbekler TM. Değişen beslenme alışkanlıkları perspektifinde takviye edici gidalar: tüketiciler ne kadar bilinçli. Social Sciences Studies Journal. 2019;5:6866-6882.

11. Ermiş E, Doğan E, Erilli NA, Satıcı A. Üniversite öğrencilerinin beslenme alışkanlıklarının incelenmesi: On dokuz Mayıs Üniversitesi örneği. Spor ve Performans Araştırmaları Dergisi. 2015;6: 30-40.

12. Göral K, Saygın Ö, Karacabey K. Amatör ve profesyonel futbolcuların beslenme bilgi düzeylerinin incelenmesi. Uluslararast Insan Bilimleri Dergisi. 2010;7:836-856.

13. Bora Z. Spor salonunda çalışan vücut geliştirme ile ilgilenen spor hocalarının beslenme ve takviye destek ürün tüketim durumlarının saptanması. Başkent Üniversitesi Sağlık Bilimleri Enstitüsü Yüksek Lisans Tezi, 2014.

14. Ergen A, Bozkurt Bekoğlu F. Türkiye'de besin destek ürünlerine yönelik görüşler ve tüketici profilini tanımlamaya yönelik bir araştırma. İşletme Araştırmaları Dergisi. 2016;241-323. 
15. Sobal J, Marquart LF. Vitamine/mineral supplement use among high school athletes. Adolescence. 2004;29(116):835-843.

16. Nieper A. Nutritial supplement practices in UK junior national track and field athletes. Br J Sports Med. 2005;39:645-649.

17. Korkmaz NH. Uludağ Üniversitesi öğrencilerinin spor yapma ve beslenme alışkanlıklarının incelenmesi. Uludağ Üniversitesi Eğitim Fakültesi Dergisi. 2010; 23(2): 399-413.

18. Yalnız İ, Gündüz N. Ankara ilinde vücut geliştirme branşında faaliyet gösteren sporcuların ergojenik yardımcilar konusunda bilgi ve uygulama düzeyleri. Gazi Beden Eğitimi ve Spor Bilimleri Dergisi. 2004;IX(2):38-39. 